\title{
Article \\ Early-Stage Detection of Solid Oxide Cells Anode Degradation by Operando Impedance Analysis
}

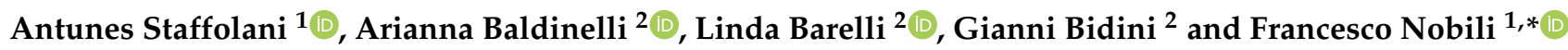 \\ 1 School of Science and Technology, Chemistry Division, Università Degli Studi di Camerino, \\ Via Sant'Agostino 1, 62032 Camerino, Italy; antunes.staffolani@unicam.it \\ 2 Department of Engineering, Università Degli Studi di Perugia, Via Duranti 93, 06125 Perugia, Italy; \\ arianna.baldinelli@unipg.it (A.B.); linda.barelli@unipg.it (L.B.); gianni.bidini@unipg.it (G.B.) \\ * Correspondence: francesco.nobili@unicam.it; Tel.: +39-0737-402216
}

check for updates

Citation: Staffolani, A.; Baldinelli, A.; Barelli, L.; Bidini, G.; Nobili, F.

Early-Stage Detection of Solid Oxide Cells Anode Degradation by Operando Impedance Analysis. Processes 2021, 9, 848. https:// doi.org/10.3390/pr9050848

Academic Editor: Domenico Frattini

Received: 26 March 2021

Accepted: 8 May 2021

Published: 12 May 2021

Publisher's Note: MDPI stays neutral with regard to jurisdictional claims in published maps and institutional affiliations.

Copyright: (c) 2021 by the authors. Licensee MDPI, Basel, Switzerland. This article is an open access article distributed under the terms and conditions of the Creative Commons Attribution (CC BY) license (https:// creativecommons.org/licenses/by/ $4.0 /)$.

\begin{abstract}
Solid oxide cells represent one of the most efficient and promising electrochemical technologies for hydrogen energy conversion. Understanding and monitoring degradation is essential for their full development and wide diffusion. Techniques based on electrochemical impedance spectroscopy and distribution of relaxation times of physicochemical processes occurring in solid oxide cells have attracted interest for the operando diagnosis of degradation. This research paper aims to validate the methodology developed by the authors in a previous paper, showing how such a diagnostic tool may be practically implemented. The validation methodology is based on applying an a priori known stress agent to a solid oxide cell operated in laboratory conditions and on the discrete measurement and deconvolution of electrochemical impedance spectra. Finally, experimental evidence obtained from a fully operando approach was counterchecked through ex-post material characterization.
\end{abstract}

Keywords: fuel cells; SOFC; electrolysis; EIS; DRT; degradation; operando; hydrogen; reversible cells

\section{Introduction}

New technology solutions for renewable energy storage are necessary for the green transition towards decarbonized and resilient energy systems. Hydrogen and fuel cells are deemed to be pivotal as they allow cross-sectoral integration (energy-transport-industry nexus) and high efficiency in electrochemical energy conversion processes. In such a technological sector, Solid Oxide Cells (SOCs) appear to be very promising [1]. In power generation, Solid Oxide Fuel Cells (SOFCs) have several advantages over state-of-the-art competitors, such as superior electric efficiency in the hydrogen-to-power process (up to $60-70 \%$, based on the hydrogen low heating value) [2], availability of high-grade heat for co-generation purposes, and almost negligible pollutant emission due to the absence of direct combustion [3]. Moreover, SOFC modules can be customized in size without losing efficiency (1 kW-1 MW) [4]. In electric energy storage processes, they are the most efficient electrolysis technology. At high temperatures (c.a. 973-1023 K), power-to-gas efficiency [5] is well beyond state-of-the-art performances achieved by commercial low-temperature electrolyzers [6] (around $80 \%$ for SOC, versus 50\% for alkaline and polymer membrane electrolyzers). In addition to that, SOCs appear promising since they support reversible operation (reversible Solid Oxide Fuel Cells, rSOC) [7]. This operation mode sounds particularly interesting when coupling the SOC unit with intermittent renewable power sources like photovoltaic [8]. The possibility to revert the cell mode operation is vital to increase the electrochemical device's utilization factor, thereby shortening the system's payback time.

According to evidence from scientific reports and literature, reversible operation may cause harsher degradation on fuel cell materials [9]. The real operation of SOCs implies cyclic temperature and load variation [10], which are responsible for undesired 
side reactions involving the SOC materials and, finally, ending in a loss of performance [11]. These problems are already debated when the same materials are employed in either single-effect fuel cell or single-effect electrolysis SOCs [12]. When it comes to the dual operation mode [13], the early detection of degradation phenomena is more complicated since degradation may be worsened by the frequent commutation in cyclic operation, beyond the effect occurring in every single operating phase.

To reach commercial maturity, lifetime, maintenance, and related costs are overriding concerns $[14,15]$. Real-time diagnosis techniques are thereby necessary to understand and measure incumbent degradation processes.

\subsection{Operando Measurement Techniques for SOC Degradation}

Performance losses often occur in SOCs, as a macroscopic effect of several degradation phenomena, such as poisoning from unwanted species like sulfur [16,17], chromium from the interconnect plates or metal piping [18-20] and chlorine [21], or maybe oxidation of nickel in the fuel electrode [22]. A concise measurement of performance losses may be done by the polarization measurements. However, this technique provides non-specific results regarding single processes.

Several techniques based on spectroscopic and electrochemical principles are available to monitor degradation phenomena and the state of health of the cell for a more detailed insight. On the one hand, spectroscopic techniques include Raman $[23,24]$, electron microscopy [25,26] and X-rays, such as X-ray diffraction and X-ray absorption [27]. The main common shortcomings are [28]: (i) the difficulty to implement such techniques, as the experiment is running, and (ii) high complexity and costs of testing apparatus. On the other hand, characterizations based on Electrochemical Impedance Spectroscopy (EIS) [29] can be applied while the cell runs without complex experimental setups. EIS is a wellknown non-destructive technique able to provide information on polarization losses due to reaction kinetics, ohmic resistances, and transport phenomena. Besides fuel cells, EIS is rather popular in electrochemical characterization techniques, from batteries to solar and microbial cells [30-32]. In SOCs, the electrochemical impedance is determined by processes such as ion and electron transport, interfacial charge transfer, gas diffusion. These processes are strongly conditioned by the electrode's microstructure (i.e., grain size, porosity, surface morphology, interfaces between material phases), which may undergo modifications as an effect of either aging or contamination during the cell lifetime. EIS data processing can be used to detect and analyze poisoning phenomena by chromium [33] and sulfur [34] or to evaluate the degradation of the electrodes, as demonstrated by Sumi et al. [35].

Over the last years, several researchers have dealt with the electrochemical characterization of SOCs through EIS [36]. In the usual practice, EIS is approximated by a complex nonlinear least squares (NLLS) function to find an equivalent circuit model (ECM) [37], which fits the experimental data. Multiple models may provide fits of the same quality [38]. However, only models with a sound physicochemical meaning can be accepted after being validated in different operating conditions. To make the identification of the ECM parameters easier, it is useful to deconvolute the measured impedance data into their components, according to their time constant $(\gamma(\tau)$, Equation (1)) [36]. This is a complementary method to the ECM approach and takes the name of distribution of relaxation time function (DRT) [39].

$$
Z(\omega)=Z_{r}(\omega)+Z_{i}(\omega)=R_{0}+Z_{p o l}(\omega)=R_{0}+R_{p o l} \int_{0}^{\infty} \frac{\gamma(\tau)}{1+j \omega \tau} d \tau
$$

Starting from previous scientific literature results, the authors proposed a diagnosis method based on operando EIS and its deconvolution by DRT, whose outcomes have been published in [40]. The study tunes this methodology on NiYSZ/8YSZ/GDC-LSCF solid oxide cells. 


\section{EIS-DRT Analysis for SOCs: A Summary}

The cell impedance may be written according to Equation (1), as a function of the frequency $\omega$, and decomposed into a pure ohmic resistance $R_{0}$ and a polarization impedance $Z_{p o l}(\omega)$. The deconvolution of $Z_{p o l}(\omega)$ into a $\gamma(\tau)$ is not trivial. Since the real $\left(Z_{r}(\omega)\right)$ and imaginary part $\left(Z_{i}(\omega)\right)$ of a linear, time-invariant system are connected by the KramersKronig transformation [41], it is sufficient to consider only $Z_{i}(\omega)$ to go through the solution of the problem Equation (2). Equation (2) is an example of Fredholm integral of the first kind, yet the inversion of the equation is an ill-posed problem leading to many possible solutions. Anyhow, it can be solved by numerical approaches [42], as explained in Section 2.2.

$$
Z_{i}(\omega)=-R_{p o l} \int_{0}^{\infty} \frac{\omega \tau}{1+(\omega \tau)^{2}} \gamma(\tau) d \tau
$$

The calculation of the function $\gamma(\tau)$ allows identification of the main physicochemical processes behind polarization losses in SOC and consequently builds an adaptive ECM suitable for real-time diagnosis. Based on the previous study made on a SOC specimen of the same typology [40], an example of DRT deconvolution from EIS measurement is reported in Figure 1 on the left side (Figure 1a), an experimental EIS characterization is shown in a Nyquist-plot fashion, while on the right side (Figure 1b), the function $\gamma(\tau)$ is plotted as a function of relaxation time. The SOC impedance is decomposed in the time domain into five different contributions, which can be ascribed to independent physicochemical phenomena.

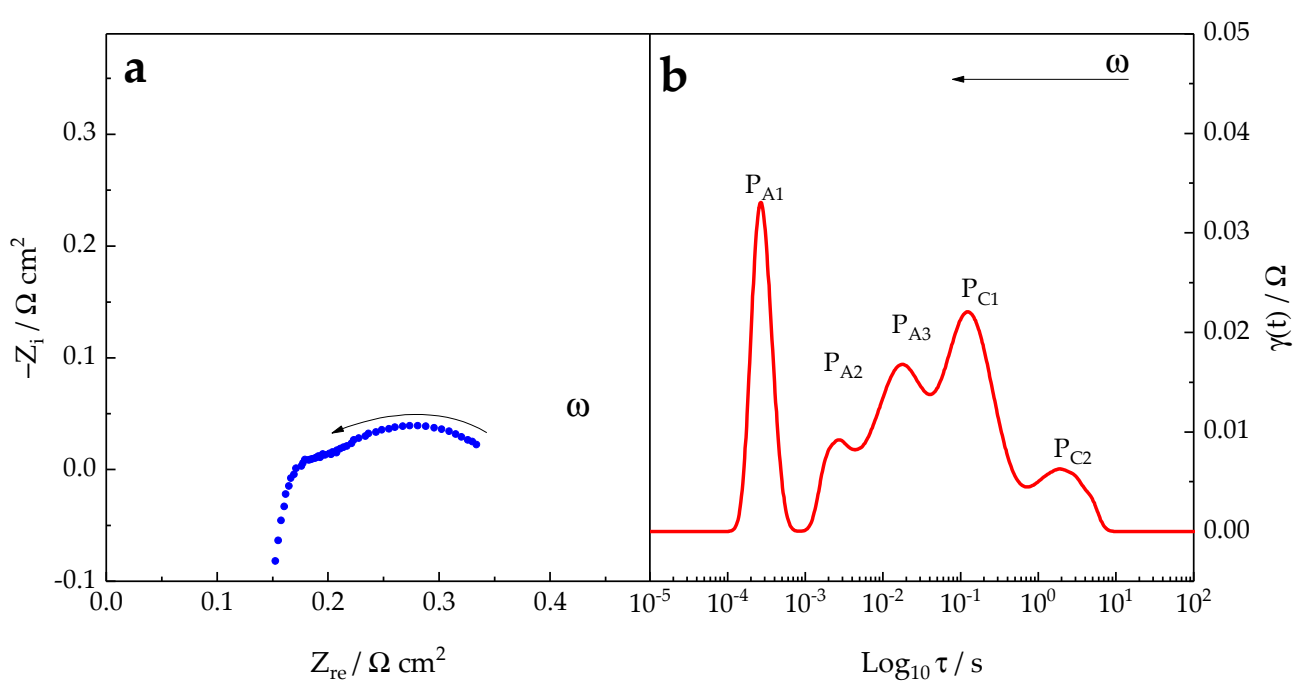

Figure 1. Typical EIS spectrum for a SOC (a), and its DRT deconvolution (b).

The EIS behavior is fitted with the ECM reported in Figure 2. Other researchers [43-45] agree on choosing this circuit for SOCs materials alike. The correlation between the deconvoluted contribution to the cell impedance (Figure 1b) and the circuital elements (Figure 2) stand as it is here explained (the nomenclature Fuel Electrode-FE-and Air ElectrodeAE—is here preferred over fuel cell "anode" and "cathode" respectively. This avoids ambiguous definitions regarding electrochemical cells in which the electrode polarity may be inverted: when rSOCs operate as electrolyzers, the FE and the AE are the cathode and anode, respectively):

- Oxygen transfer at the FE is highlighted by a peak in the DRT at $\tau=10^{-4} \mathrm{~s}\left(\mathrm{P}_{\mathrm{A} 1}\right)$; moreover, it is modeled with a parallel Resistance//Constant Phase Element $\left(\mathrm{R}_{\mathrm{a} 1} \mathrm{Q}_{\mathrm{a} 1}\right)$;

- The Hydrogen Oxidation Reaction (HOR) at the fuel electrode yields a peak at $\tau=10^{-3} \mathrm{~S}\left(\mathrm{P}_{\mathrm{A} 2}\right)$ and it corresponds to a parallel Resistance//Constant Phase Element $\left(\mathrm{R}_{\mathrm{a} 2} \mathrm{Q}_{\mathrm{a} 2}\right)$; 
- Similarly, the Oxygen Reduction Reaction (ORR) at the AE is modeled with another parallel Resistance//Constant Phase Element $\left(\mathrm{R}_{\mathrm{c} 1} \mathrm{Q}_{\mathrm{c} 1}\right)$ and it gives a peak in the DRT at $\tau=10^{-1} \mathrm{~s}\left(\mathrm{Pc}_{1}\right)$.

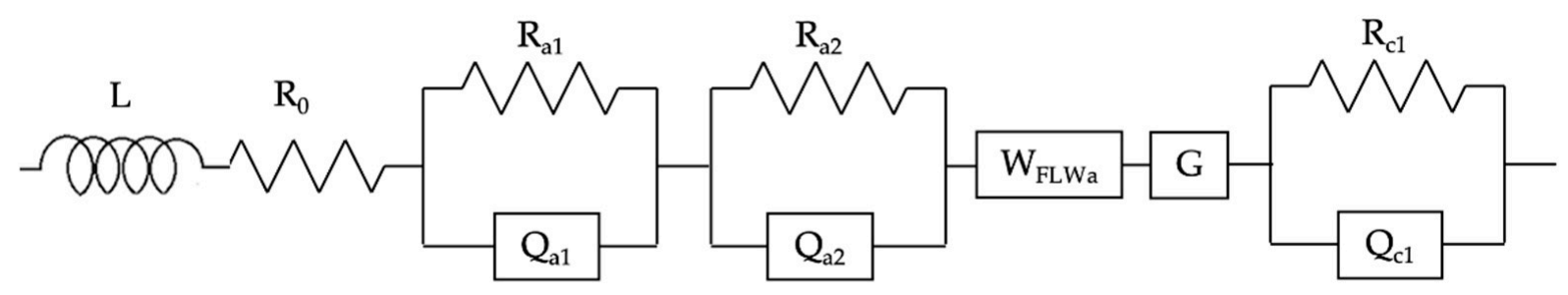

Figure 2. Equivalent circuit model for the SOC type used in this experiment. The model is tuned on a cell with a NiYSZ fuel electrode and GDC/LSCF air electrode.

Note that constant phase elements are used instead of pure capacitors in the circuit to consider electrodes' inhomogeneity and roughness [46]. Then, two diffusive elements $[29,47]$ are used to model the diffusion in the FE and the mixed ionic electronic conductor AE. Namely, they are:

- A finite-length Warburg element $\left(\mathrm{W}_{\mathrm{FLWa}}\right)$ modeling the gas transport to the fuel electrode. This process is highlighted by the peak at $\tau=10^{-2} \mathrm{~s}\left(\mathrm{P}_{\mathrm{A} 3}\right)$;

- A Gerischer element $(G)$, standing for gas transport at the mixed ionic-electronic conductor (MIEC) AE. It corresponds to the signal at $\tau=10 \mathrm{~s}\left(\mathrm{P}_{\mathrm{C} 1}\right)$.

$\mathrm{R}_{0}$ models the ion conduction in the electrolyte, and it can be immediately identified in the Nyquist plot representation as the positive shift from the origin in the $Z_{r}$ axis. Finally, an inductor $\mathrm{L}$ fits the inductive feature at high frequency due to cell geometry and wiring.

According to the operating condition of the SOC, each contribution to the overall impedance may either increase or decrease. Hence, a comprehensive overview of the physicochemical phenomena is reported in Table 1, together with an explicit notation for the ECM elements and a simplified overview of the process variables affecting them. Each circuital element coefficient depends on the process variables, like temperature, reactive gas concentration and flow rates, and current density. When a complete library of the circuital coefficients is available to describe the new\&clean condition for the SOC operation, the ECM can be used as a useful reference model to detect cell degradation and isolate the principal cause leading to a global increase of performance losses.

Table 1. Physicochemical phenomena occurring in the SOC vs. ECM notation.

\begin{tabular}{|c|c|c|c|}
\hline Phenomenon & Variation With: & DRT Peak & ECM Element \\
\hline Oxygen transport & Temperature & $\mathrm{P}_{\mathrm{A} 1}$ at $\tau=10^{-4} \mathrm{~s}$ & $\mathrm{R}_{\mathrm{a} 1} \mathrm{Q}_{\mathrm{a} 1}=\frac{R_{a 1}}{1+R_{a 1} Q_{a 1}(j \omega)^{a_{a 1}}}$ \\
\hline $\mathrm{HOR}$ & $\begin{array}{l}\text { Hydrogen partial pressure, } \\
\text { catalytic activity at the FE, } \\
\text { temperature }\end{array}$ & $\mathrm{P}_{\mathrm{A} 2}$ at $\tau=10^{-3} \mathrm{~s}$ & $\mathrm{R}_{\mathrm{a} 2} \mathrm{Q}_{\mathrm{a} 2}=\frac{R_{a 2}}{1+R_{a 2} \mathrm{Q}_{a 2}(j \omega)^{\alpha} a 2}$ \\
\hline ORR & $\begin{array}{l}\text { Oxygen partial pressure, catalytic } \\
\text { activity at the } \mathrm{AE} \text {, temperature }\end{array}$ & $\mathrm{P}_{\mathrm{C} 1}$ at $\tau=10^{-1} \mathrm{~s}$ & $\mathrm{R}_{\mathrm{c} 1} \mathrm{Q}_{\mathrm{C} 1}=\frac{R_{c 1}}{1+R_{c 1} Q_{c 1}(j \omega)^{\alpha_{c 1}}}$ \\
\hline Mass transport FE (NiYSZ) & $\begin{array}{c}\text { Reactants space velocity, } \\
\text { utilization rate (current density) } \\
\text { at the FE }\end{array}$ & $\mathrm{P}_{\mathrm{A} 3}$ at $\tau=10^{-2} \mathrm{~s}$ & $=R_{W}(j \omega \tau)^{-1 / 2} \tanh (j \omega \tau)^{1 / 2}$ \\
\hline $\begin{array}{l}\text { Mass transport AE } \\
\quad(\mathrm{GDC} / \mathrm{LSCF})\end{array}$ & $\begin{array}{c}\text { Reactants space velocity, } \\
\text { utilization rate (current density) } \\
\text { at the } \mathrm{AE}\end{array}$ & $\mathrm{P}_{\mathrm{C} 2}$ at $\tau=10 \mathrm{~s}$ & $\mathrm{G}=\frac{1}{Y \sqrt{k+j \omega}}$ \\
\hline Electrolyte & Temperature & - & $\mathrm{R}_{0}$ \\
\hline Wiring-Cell geometry & Not relevant & - & $L j$ \\
\hline
\end{tabular}




\subsection{Aim of the Study}

This research paper aims to validate the methodology developed by the authors in [40], hence showing how the technique may be implemented for the operando diagnosis of faults and aging of SOCs. While this study overlooks applications of SOCs in reversible operation, the technique is developed to be applied in the fuel cell working mode since electrical signals and power flows from the cell are more stable and more comfortable to be deconvoluted.

\section{Materials and Methods}

This section provides detailed instructions about the realization of the physical experiment (Section 2.1) and the methodology implemented while post-processing the experimental measurements (Section 2.2). Comprehensively, the methodology followed abides by the workflow sketched in the chart in Figure 3.

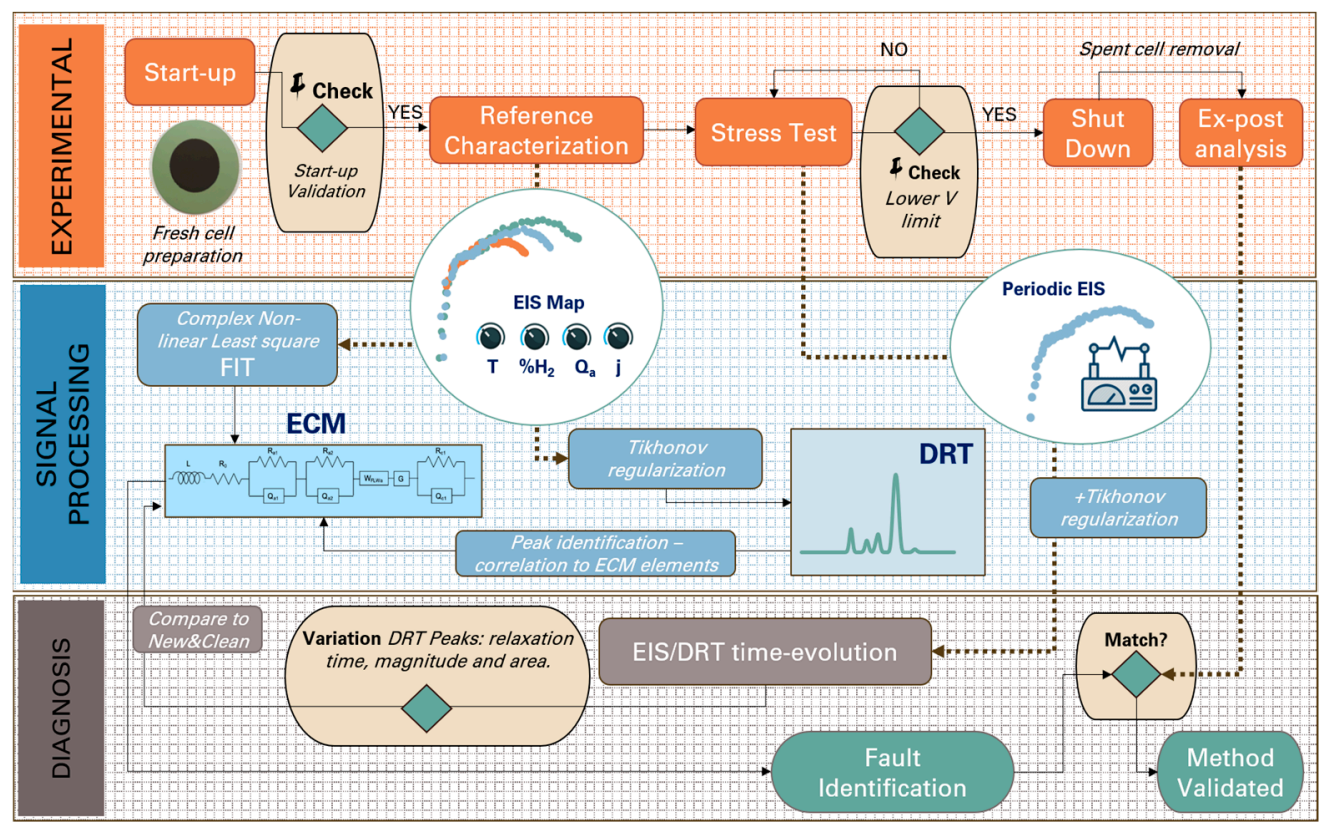

Figure 3. Conceptual workflow chart.

\subsection{Experimental}

\subsubsection{Materials}

Experiments were performed on a planar two-electrode round cell, with an active surface area of $1 \mathrm{~cm}^{2}$. The cell composition and geometric features are reported briefly in Table 2. Before running the experiments, the cell was sealed onto an alumina housing with Schott G018-311 (Schott AG, Mainz, Germany).

Table 2. Solid oxide cell features.

\begin{tabular}{ccc}
\hline Layer & Composition & Thickness \\
\hline Fuel Electrode & NiYSZ & $240 \mu \mathrm{m}$ \\
\hline Electrolyte & 8 YSZ & $8 \mu \mathrm{m}$ \\
\hline Air Electrode & GDC-LSCF & $50 \mu \mathrm{m}$ \\
\hline
\end{tabular}

A schematic of the testing apparatus is displayed in Figure 4. The cell housing was placed into a temperature-controlled electric furnace equipped with two K-thermocouples for temperature regulation (TR) and measurement (TM). The cell was fed with technicalpurity gases conveyed by alumina pipes. Regarding gas flow rate regulation, the test bench 
was equipped with Vögtlin Red-y Smart digital mass flow meter controllers (FMC), one for each gas feed. The instrument accuracy was $0.2 \%$ on the full scale $(200 \mathrm{Sml} / \mathrm{min}$ for hydrogen and nitrogen, $1000 \mathrm{Sml} / \mathrm{min}$ regarding air). On the fuel gas line side, a roomtemperature humidifier was interposed between the gas flow meters and the piping reaching the inner part of the housing. The electrodes were covered with high-purity metal meshes to realize a proper gas distribution over the cell electrodes, together with good electric contact. In detail, the mesh for the air electrode (cathode in fuel cell operation) was made of $99.999 \%$ purity gold, while the one for the fuel electrode (anode in fuel cell operation) by $99.999 \%$ purity nickel. Each metal mesh was connected to voltage sensors and a DC load circuit. All electrical measurements are performed with a Keysight DAQ system (accuracy $0.0004 \%$ ). The standard operation of the fuel cell was managed with Lab-view software developed in-house. For impedance measurement, the analyzer Biologic SP-240 was used, and data were acquired and processed by the software EC-Lab.

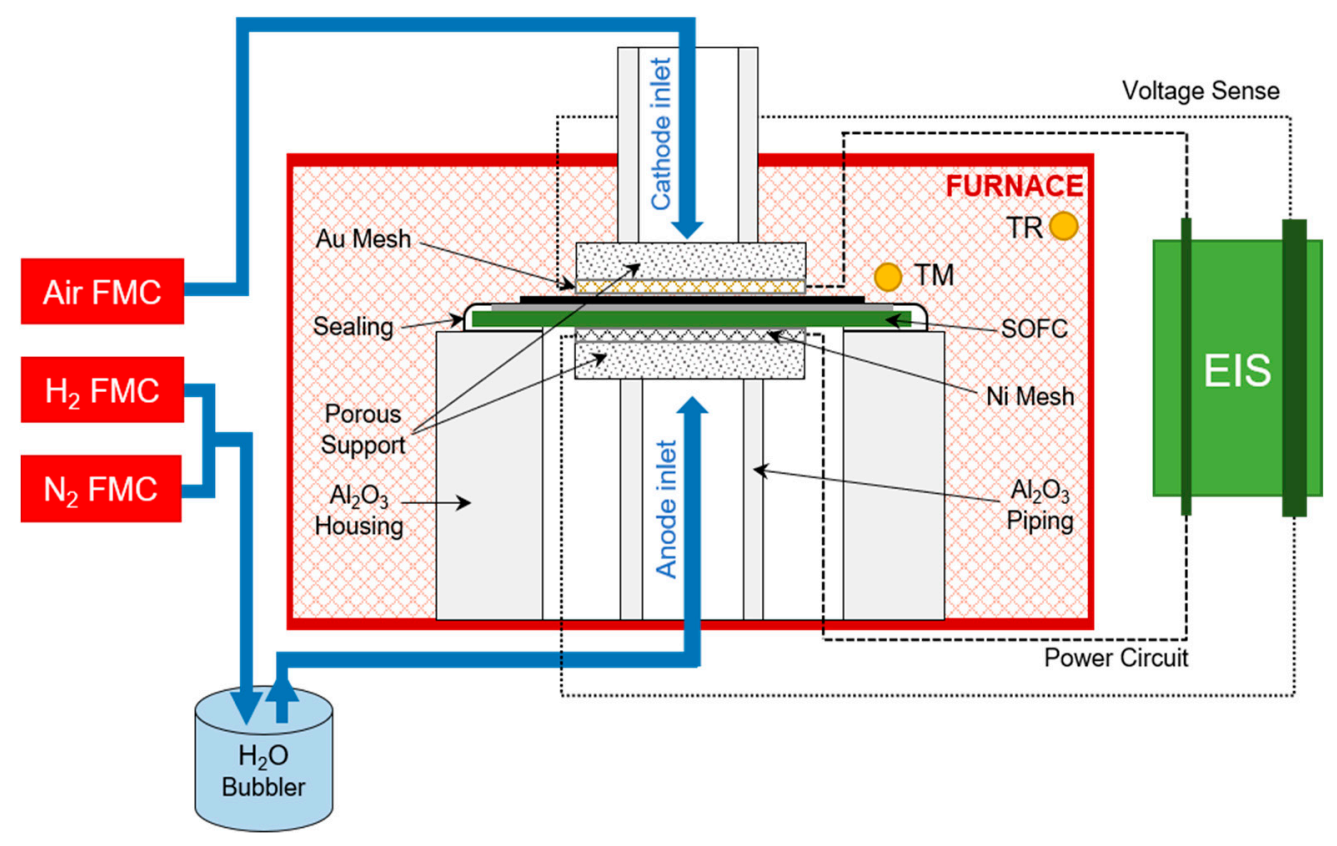

Figure 4. Testing apparatus schematic (cell, housing, and measurement hardware).

\subsubsection{Methods}

The testing protocol is described in terms of both operating conditions and instructions to perform measurements. SOC operating settings are resumed in Table 3 for each phase. The operating voltage and current of the cell were continuously measured and saved throughout the entire test duration.

Below the test phases:

1. Start-up: When starting the test, the sealing paste is cured according to the instructions provided by the supplier, without exceeding a temperature rising rate of $1 \mathrm{~K} / \mathrm{min}$. During this phase, the cell is supplied with nitrogen at the fuel electrode and air at the air electrode. Once $1073 \mathrm{~K}$ are reached, the fuel electrode catalyst reduction begins.

2. Reduction: Nitrogen is gradually substituted with hydrogen to reduce the fuel electrode catalysts from $\mathrm{NiO}$ to $\mathrm{Ni}$.

3. Stabilization: The cell is stabilized for at least $100 \mathrm{~h}$ at $1073 \mathrm{~K}$, exposing the fuel electrode to a pure hydrogen atmosphere. A constant mild current load $\left(250 \mathrm{~mA} / \mathrm{cm}^{2}\right)$ is set.

4. Begin Reference: Reference performances are acquired at $1048 \mathrm{~K}$, feeding the fuel electrode with a mixture of hydrogen $(50 \mathrm{Sml} / \mathrm{min})$ and nitrogen $(150 \mathrm{Sml} / \mathrm{min})$. The air electrode gas supply does not change (air, $300 \mathrm{Sml} / \mathrm{min}$ ). Reference performance is characterized by both polarization and impedance analysis. For the further, the i-V 
curve of the cell is sampled with a potentiostat method, varying the working electrode potential from Open Circuit (OC) down to $0.7 \mathrm{~V}$, by a rate of $-40 \mathrm{mV} / \mathrm{min}$, and then reverting to $\mathrm{OC}$ with a rising ramp of $+40 \mathrm{mV} / \mathrm{min}$. Then, for the latter, impedance is measured in galvanostatic mode with a single-sine method, applying a current wave of $20 \mathrm{~mA}$ amplitude. Electrochemical impedance is scanned from $100 \mathrm{kHz}$ down to $100 \mathrm{MHz}$, acquiring 10 points per frequency decade, logarithmically spaced. Every single measurement is the average of 6 samplings. Impedance spectra are sampled at different selected points on the $\mathrm{i}-\mathrm{V}$ curve $\left(0,100,250,500\right.$, and $\left.750 \mathrm{~mA} / \mathrm{cm}^{2}\right)$. Both techniques are implemented through a BioLogic SP-240 analyzer, setting a voltage range of $0.5-1.5 \mathrm{~V}$ (resolution $20 \mu \mathrm{V}$ ) and a current range of $4 \mathrm{~A}$.

5. Stress test: The cell temperature is kept at $1048 \mathrm{~K}$ and the gas flow rates and composition at both electrodes do not change regarding the reference characterization. The cell is continuously operated at $1500 \mathrm{~mA} / \mathrm{cm}^{2}$ for time intervals of $4 \mathrm{~h}$. After each 4-h time interval, the cell is brought back to OC to perform a galvanostatic EIS scan. The settings are the same as above: $20 \mathrm{~mA}$ single-sine current wave, 10 points per frequency decade, logarithmic spacing, 6 samplings per point. The impedance analysis is carried out at three current values of the polarization curve $\left(0,250,500 \mathrm{~mA} / \mathrm{cm}^{2}\right)$, with both forward (from $100 \mathrm{kHz}$ down to $100 \mathrm{MHz}$ ) and backward frequency scan (from $100 \mathrm{MHz}$ up to $100 \mathrm{kHz}$ ). After the EIS characterization, constant load operation at $1500 \mathrm{~mA} / \mathrm{cm}^{2}$ is restored for the following $4 \mathrm{~h}$. This process is iterated as long as the working electrode potential is above $0.60 \mathrm{~V}$.

6. End Point: The final characterization is performed in the same conditions set for the beginning reference test. Both polarization and impedance are recorded, following the procedure already presented at the previous point 4.

7. Shut down: The electric load is disconnected. Then, the cell is cooled down to room temperature (RT) with a decreasing temperature rate of $-1 \mathrm{~K} / \mathrm{min}$, supplying former gas at the fuel electrode (hydrogen $5 \mathrm{Sml} / \mathrm{min}+$ nitrogen $95 \mathrm{Sml} / \mathrm{min}$ ) and nitrogen at the air electrode $(100 \mathrm{Sml} / \mathrm{min})$.

Table 3. Test protocol: electrode feeding gases flowrates and composition, and cell operating settings (Legend: $X=$ volume composition $\left[\%_{\mathrm{vol}}\right.$ dry basis $], Q=$ volume flow rate $[\mathrm{Sml} / \mathrm{min}], \mathrm{T}=$ temperature $[\mathrm{K}]$. The stress test is repeated until a noticeable performance decay is measured.

\begin{tabular}{|c|c|c|c|c|c|c|c|}
\hline \multirow{2}{*}{$\begin{array}{c}\text { TEST } \\
\text { ID }\end{array}$} & \multicolumn{2}{|c|}{$\begin{array}{c}\text { Fuel } \\
\text { Electrode }\end{array}$} & \multicolumn{2}{|l|}{$\begin{array}{c}\text { Air } \\
\text { Electrode }\end{array}$} & \multicolumn{2}{|c|}{$\begin{array}{l}\text { Operating } \\
\text { Settings }\end{array}$} & \multirow{2}{*}{$\begin{array}{c}\text { Duration } \\
\text { Hours }\end{array}$} \\
\hline & $X$ & $\mathbf{Q}$ & $x$ & $\mathbf{Q}$ & $\mathbf{T}$ & Load & \\
\hline Start-up & $100 \% \mathrm{~N}_{2}$ & 50 & $21 \% \mathrm{O}_{2}+79 \% \mathrm{~N}_{2}$ & 300 & $\mathrm{RT}^{1} \rightarrow 1073$ & OC & $16 \mathrm{~h}$ \\
\hline Reduction & $\begin{array}{c}100 \% \mathrm{~N}_{2} \rightarrow \\
100 \% \mathrm{H}_{2}\end{array}$ & 150 & $21 \% \mathrm{O}_{2}+79 \% \mathrm{~N}_{2}$ & 300 & 1073 & OC & $1.5 \mathrm{~h}$ \\
\hline Stabilization & $100 \% \mathrm{H}_{2}$ & 150 & $21 \% \mathrm{O}_{2}+79 \% \mathrm{~N}_{2}$ & 300 & 1073 & $\begin{array}{l}\text { Constant } \mathrm{j}= \\
250 \mathrm{~mA} / \mathrm{cm}^{2}\end{array}$ & $100 \mathrm{~h}$ \\
\hline Begin Ref & $\begin{array}{c}25 \% \mathrm{H}_{2}+ \\
75 \% \mathrm{~N}_{2}\end{array}$ & 200 & $21 \% \mathrm{O}_{2}+79 \% \mathrm{~N}_{2}$ & 300 & 1048 & $\begin{array}{c}\mathrm{i}-\mathrm{V}: \mathrm{OC} \rightarrow 0.7 \mathrm{~V} \\
\text { EIS: } 0,100,250 \\
500,750 \mathrm{~mA} / \mathrm{cm}^{2}\end{array}$ & $\begin{array}{c}30 \mathrm{~min} \\
1 \mathrm{~h}\end{array}$ \\
\hline $\begin{array}{l}\text { Stress test } \\
\text { (repeated) }\end{array}$ & $\begin{array}{c}25 \% \mathrm{H}_{2}+ \\
75 \% \mathrm{~N}_{2}\end{array}$ & 200 & $21 \% \mathrm{O}_{2}+79 \% \mathrm{~N}_{2}$ & 300 & 1048 & $\begin{array}{c}\text { Constant } \mathrm{j}= \\
1500 \mathrm{~mA} / \mathrm{cm}^{2} \\
\text { EIS: } 0,100,250, \\
500 \mathrm{~mA} / \mathrm{cm}^{2}\end{array}$ & $\begin{array}{c}4 \mathrm{~h} \\
30 \mathrm{~min}\end{array}$ \\
\hline End Point & $\begin{array}{c}25 \% \mathrm{H}_{2}+ \\
75 \% \mathrm{~N}_{2}\end{array}$ & 200 & $21 \% \mathrm{O}_{2}+79 \% \mathrm{~N}_{2}$ & 300 & 1048 & $\begin{array}{c}\mathrm{i}-\mathrm{V}: \mathrm{OC} \rightarrow 0.7 \mathrm{~V} \\
\text { EIS: } 0,100,250 \\
500,750 \mathrm{~mA} / \mathrm{cm}^{2}\end{array}$ & $\begin{array}{l}30 \mathrm{~min} \\
1 \mathrm{~h}\end{array}$ \\
\hline Shut down & $\begin{array}{c}5 \% \mathrm{H}_{2}+95 \% \\
\mathrm{~N}_{2}\end{array}$ & 100 & $100 \% \mathrm{~N}_{2}$ & 100 & $1073 \rightarrow \mathrm{RT}$ & OC & c.a. $12 \mathrm{~h}$ \\
\hline
\end{tabular}




\subsubsection{Cell Material Characterization}

After the test is concluded, the exhausted SOC specimen is used for material postanalysis. The morphology of both cell face and section is characterized using a scanning electron microscope (ZEISS Sigma Series 300 FE-SEM). Raman spectra are recorded on a Horiba iH320 spectrometer with a $532 \mathrm{~nm}$ laser source. The material characterization is performed on the cell used for the experiment and on two other samples: on the one hand, a new cell as it comes from the supplier and, on the other hand, a new cell after a chemical reduction.

\subsection{Impedance Data Post-Processing}

The deconvolution of the impedance spectrum is done by applying a DRT function based on Tikhonov regularization. Therefore, a regularization parameter of $\lambda=0.001$ is used to deconvolute the experimental data. The inductive feature in the high-frequency region due to the cell geometry and electrical wiring was cut before the DRT data-processing. Complex non-linear least square fit was pursued by using the equivalent circuit model $\mathrm{L}-\mathrm{R}_{0^{-}}$ $\left(R_{A 1}\right)-\left(R_{A} 2\right)-W_{F L W}-G-\left(R Q_{C 1}\right)$, already discussed in the previous section. In spectrum fitting, the inductive feature has not been cut and was modeled by adding an inductor element in the ECM. All the $\chi^{2}$ obtained from fitting were in the order of $10^{-5}-10^{-6}$. The Kramer-Kronig Transform test and residual analysis were done using the imaginary part of the impedance spectrum. Data processing concerning the impedance data was pursued using the impedance analysis software Relaxis3 from the RHD instrument.

\section{Results}

This section presents experimental results and their post-processing. Section 3.1 shows the whole history of the stress test and the reference tests, reporting the measured voltage evolution and $\mathrm{i}-\mathrm{V}$ curves, respectively. Then, Section 3.2 shows and comments about the evolution of the cell impedance through the DRT and ECM approach. Finally, the operando investigation's main outcomes are validated with material post-mortem analysis in Section 3.3 (following the workflow reported in Figure 3).

\subsection{Experimental}

The cell under test completed $32 \mathrm{~h}$ in the stress test conditions (8 intervals of $4 \mathrm{~h}$ each). After the 8th interval, the average voltage measured over the last $4 \mathrm{~h}$ was below the warning threshold of $0.6 \mathrm{~V}$. Consequently, the stress test ceased. The i-V characterization reported in Figure 5 shows the global performance loss scored. From Figure 5, it is clear that the endpoint test curve (red curve, $\mathrm{i}-\mathrm{V}$ end) is below the begin reference curve (blue curve, $\mathrm{i}-\mathrm{V}$ begin) in the whole operating range investigated. The gap increases with current density. Despite that, as profoundly debated in the introduction, this technique does not provide information about single processes deviating from the initial state.

Figure 6 reports the stress test history, clearly showing that the stress test comprises eight 4-h intervals, spaced out by EIS measurements (each lasting about $30 \mathrm{~min}$ ). The current density was kept at $1500 \mathrm{~mA} / \mathrm{cm}^{2}$ in all intervals, as planned. In the first three intervals, the cell voltage was relatively stable around an average value of $0.643 \mathrm{~V}$. In interval IV, a sudden voltage drop appeared $(-30 \mathrm{mV})$. Then, the cell voltage kept stable in intervals $\mathrm{V}$ and VI $(0.615 \mathrm{~V})$, and finally, it smoothly decreased in the last two intervals. The test was stopped after falling below the $0.600 \mathrm{~V}$ warning threshold.

\subsection{Diagnosis Investigation}

Figure 7a reports a typical impedance Nyquist plot of the cell under investigation. It is characterized by: (i) an inductive feature at high frequencies due to the electrical wiring and cell geometry, (ii) a small depressed semi-circle at high frequencies, and (iii) a bigger semi-circle in the mid-low frequency region. Then, the deconvolution of the physical and electrochemical processes occurring inside the cell was done through their characteristic relaxation times (Figure $7 \mathrm{~b}$ ). Before doing that, the quality of the impedance data was 
assessed by analyzing the Kramer-Kronig residuals in the imaginary part of the spectrum, as shown in Figure 7c. Most of the residuals fell below the $0.5 \%$ threshold. Nonetheless, at mid-high frequencies $\left(10^{3}-10^{4} \mathrm{~Hz}\right)$, this threshold was almost reached, and it can be referred to as the unwanted inductive feature.

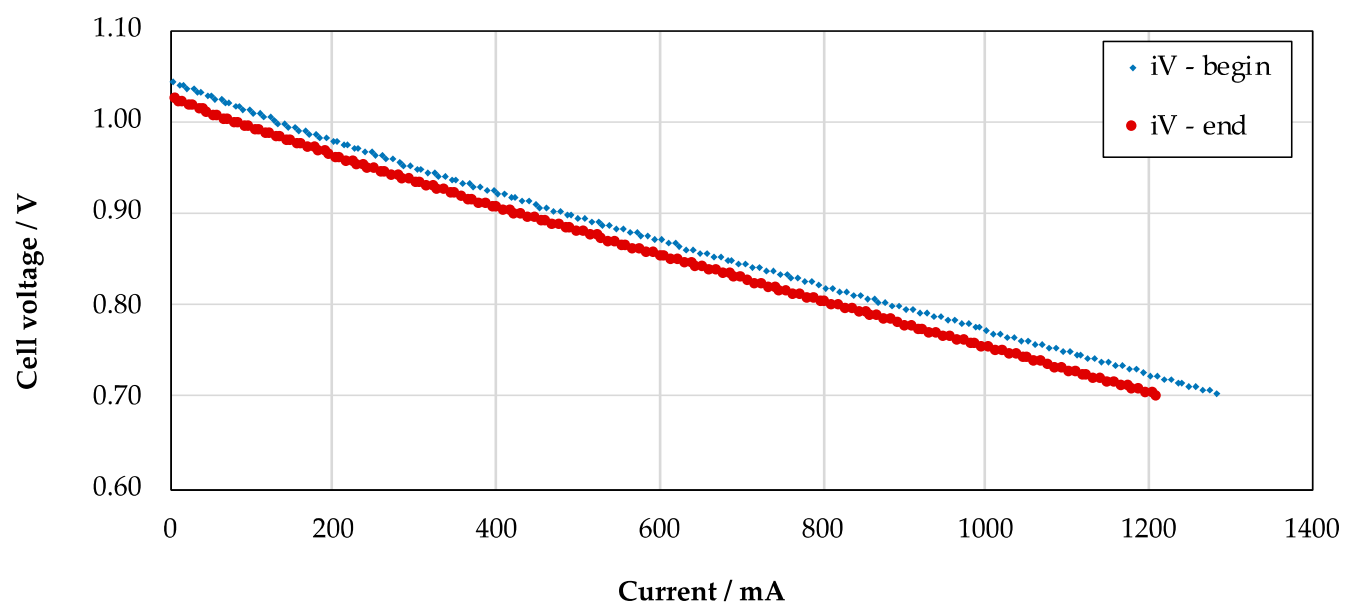

Figure 5. Polarization characterization: Begin reference versus endpoint i-V curve.

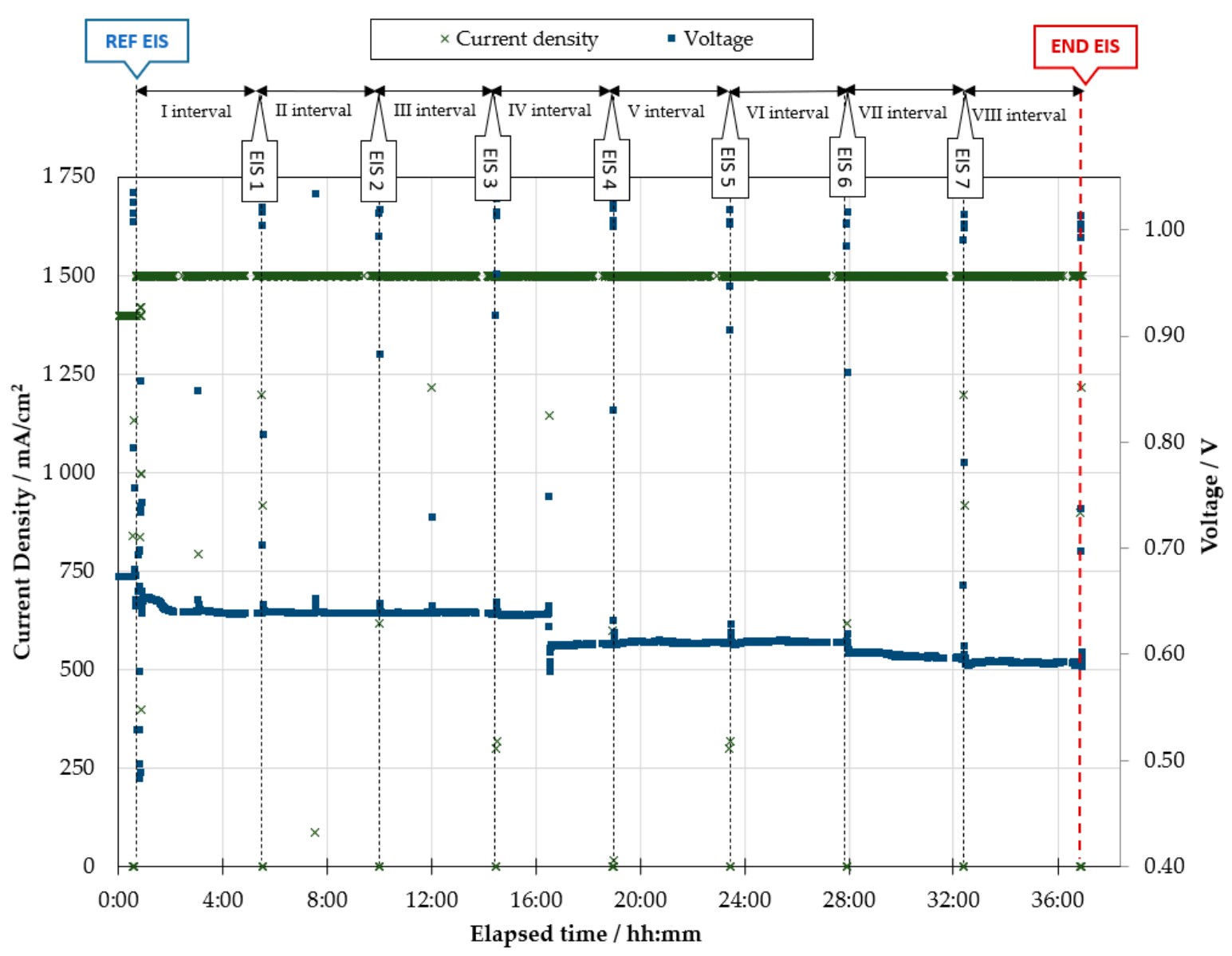

Figure 6. Test history through voltage and current data logs. Monitoring spots are flagged. 


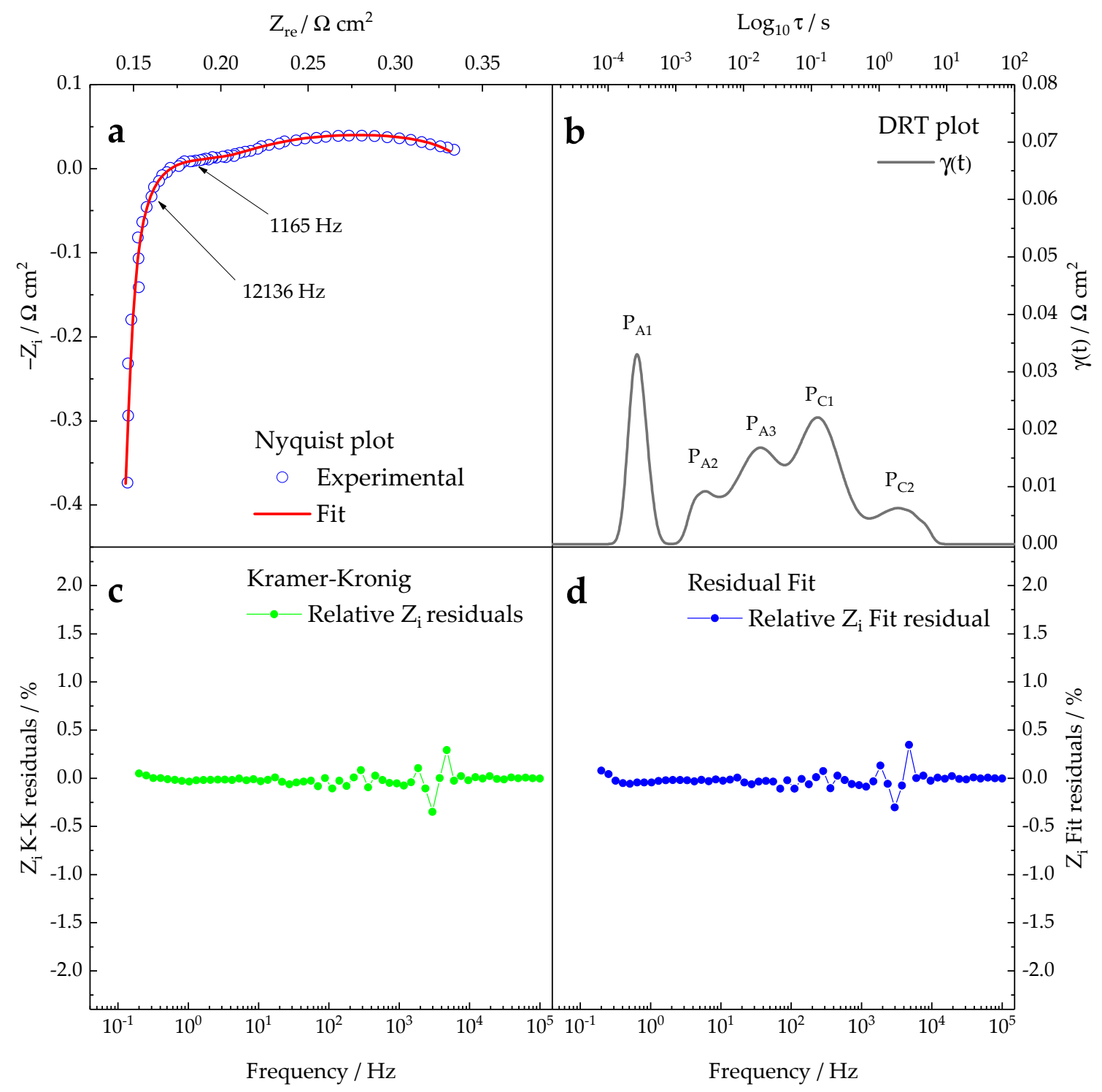

Figure 7. (a) Experimental (blue empty scatter) and Fitted (solid red line) impedance spectrum acquired at $1048 \mathrm{~K}$ with $\mathrm{H}_{2}: \mathrm{N}_{2}$ 25:75 $200 \mathrm{Sml} / \mathrm{min}$ at the anode and air at $300 \mathrm{Sml} / \mathrm{min}$ at the AE, (b) DRT of the impedance spectrum with the assigned peaks, (c) Kramer-Kronig residuals of the real part of the impedance spectrum, (d) residuals of the real part of impedance spectrum after fitting with the proposed ECM.

The data were deconvoluted by the Tikhonov Regularization. At least five peaks are resolved and, by an extended experimental campaign, assigned to different physical and chemical processes—as explained in Section 1 . Then, the impedance spectrum was fitted with the proposed ECM shown in Figure 2. The fitting procedure led to a $\chi^{2}=10^{-5}-10^{-6}$, and residuals (shown in Figure $7 \mathrm{~d}$ ) mostly $\leq 0.5 \%$. As for the Kramer-Kronig residuals, only at high frequencies, this limit was almost reached.

As mentioned in Section 2, impedance spectra were collected during the stress test every $4 \mathrm{~h}$ to monitor the cell state of health. Figure 8 reports impedance arcs measured in three checkpoints of the stress test, namely:

- Figure 8a: begin of stress test (begin reference), corresponding to the label "REF EIS" from Figure 6;

- $\quad$ Figure 8b: after $28 \mathrm{~h}$ from the start, corresponding to the label "EIS 6" from Figure 6

- $\quad$ Figure 8c: end of the experiment (end point), corresponding to the label "END EIS" from Figure 6. 

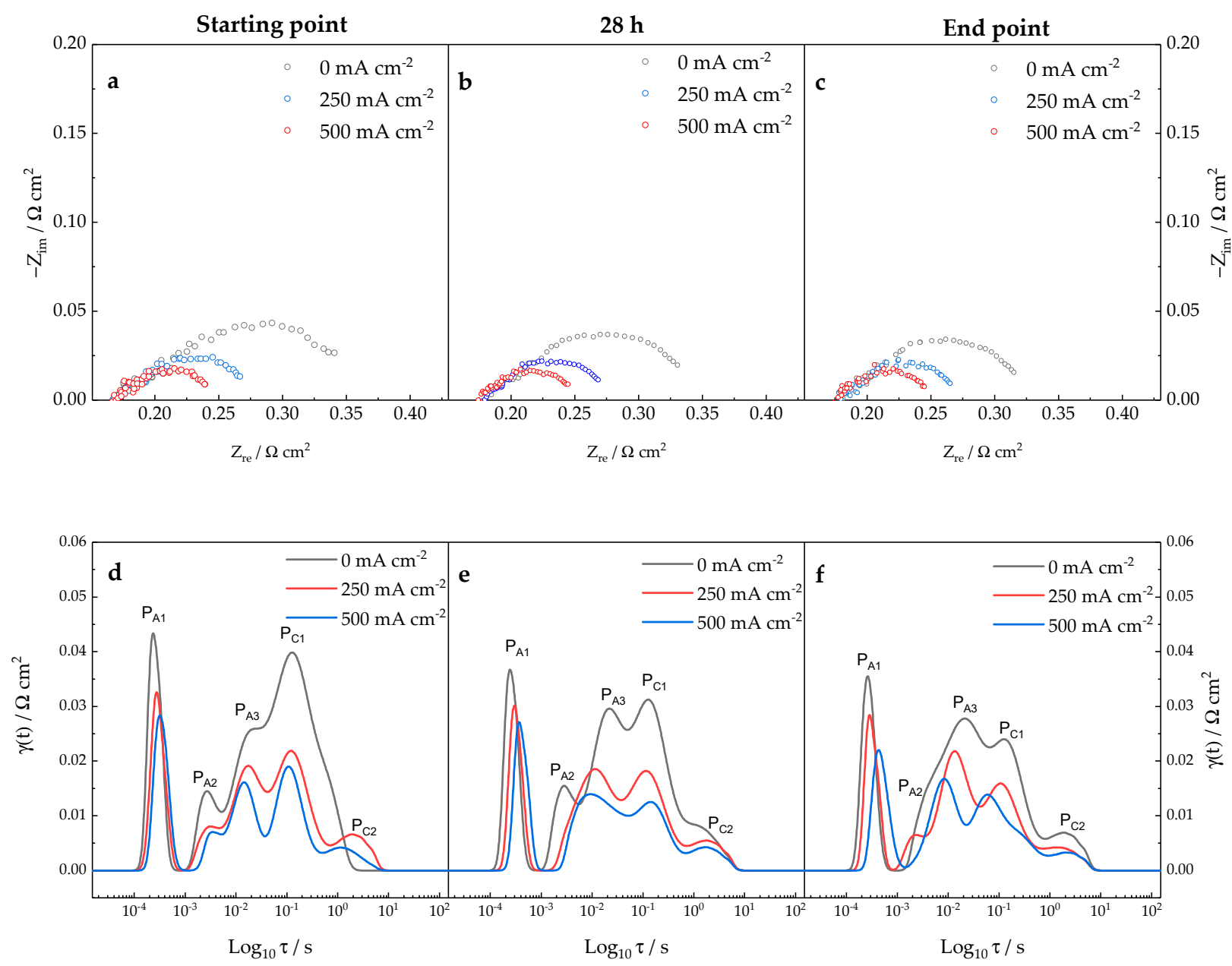

Figure 8. Nyquist plots acquired at begin ref (a), after $28 \mathrm{~h} \mathrm{(b)}$, and at the endpoint of the experiment (c) at three different current densities, i.e., 0,250 , and $500 \mathrm{~mA} / \mathrm{cm}^{2}$; DRT plot of the above-mentioned impedance spectrum: begin ref (d), after $28 \mathrm{~h}(\mathbf{e})$, and at the endpoint of experiment (f).

As the applied current density increases, the dispersion maintains the same shape, and the overall impedance decreases. Interestingly, as the experiment proceeds, the impedance becomes slightly smaller.

Looking at the DRT deconvolution in Figure $8 \mathrm{~d}-\mathrm{f}$, the distribution decreases in all cases as the current increases. Simultaneously, while the experiment goes forward, the area and the relaxation time of the peaks change, especially regarding the two peaks $\mathrm{P}_{\mathrm{A} 2}$ and $\mathrm{P}_{\mathrm{A} 3}$ related to HOR and the hydrogen diffusion in the fuel electrode. To have a clearer view, the peaks were fitted with a gaussian function (Equation (3), where $A, w, y_{0}$, and $x_{c}$ stand for the area, the width, the minimum height, and the center point of each peak, respectively) to monitor how the center point and area of the peaks change as the experiment progresses:

$$
y=y_{0}+\frac{A}{w \sqrt{\frac{\pi}{2}}} e^{\frac{-2\left(x-x_{c}\right)^{2}}{w w^{2}}}
$$

Thereby, the DRT plot was fitted until reaching a $x^{2}=10^{-9}$. An example spectrum is shown in Figure 9. The peak's shape was totally fitted and, at the same time, information about the peak's area and relaxation time were acquired. 


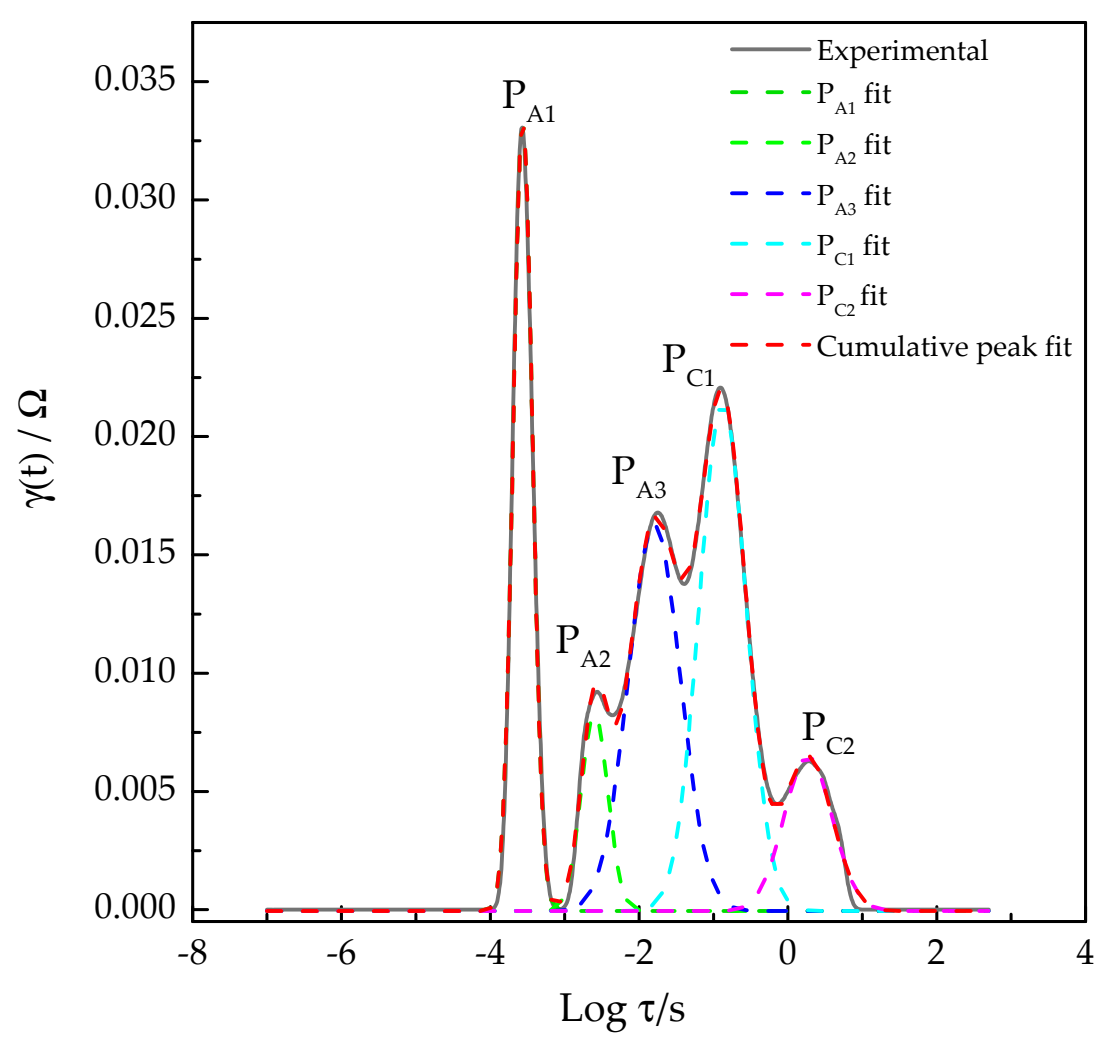

Figure 9. Fitted DRT plot by the Gaussian function. The shape of the peaks is highlighted.

Figure 10 reports the relaxation time and the area of each peak vs the experiment time at $250 \mathrm{~mA} / \mathrm{cm}^{2}$. In all cases, the relaxation time and the area oscillated during the experiment. This could be due to oscillations coming from data acquisition and elaboration within the experimental error. Looking at the general trend, some peaks had a considerable change in both relaxation time and area. Specifically, after $\approx 16 \mathrm{~h}$ both peaks $\mathrm{P}_{\mathrm{A} 2}$ and $\mathrm{P}_{\mathrm{A} 3}$ (HOR and the hydrogen diffusion in the fuel electrode) had a complete change in their shape and $\tau$, while $\mathrm{P}_{\mathrm{A} 1}$ had a small change after few hours from the start. This feature was in good agreement with the $E$ vs. $t$ and $I$ vs. $t$ plots reported in Figure 6 , in which at the interval IV, there was a sudden voltage drop at $\approx 16 \mathrm{~h}$. $\mathrm{P}_{\mathrm{A} 2}$ area increases and shifts to higher relaxation times, meaning that somehow the HOR's kinetic started worsening, increasing the contribution of this phenomenon to the overall impedance. In the case of $\mathrm{P}_{\mathrm{A} 3}$, one can remark a decrease in the area (and lower related impedance). However, this change is less noticeable than $\mathrm{P}_{\mathrm{A} 2}$.

Then, in Figure 11, the relaxation time and the area of each peak vs the experiment time at $500 \mathrm{~mA} / \mathrm{cm}^{2}$ are shown. In this case, smaller changes can be noticed.

This can be attributable to the overall impedance decrease caused by the higher applied current density. The peak $\mathrm{P}_{\mathrm{A} 1}$ had similar behavior to the previous case $\left(\mathrm{j}=250 \mathrm{~mA} / \mathrm{cm}^{2}\right)$, with an increase of relaxation time and decrease of the peak area after a few hours from the start of the experiment. As in the first case, the $\mathrm{P}_{\mathrm{A} 2}$ relaxation time increases, and the $\mathrm{P}_{\mathrm{A} 3}$ area decreases after $\approx 30 \mathrm{~h}$ from the start of the experiment.

Concerning the cathodic peaks, at both applied current densities, $\mathrm{P}_{\mathrm{C} 1}$ had small changes at the end of the experiment, probably due to the HOR and the ORR interrelation. In contrast, $\mathrm{P}_{\mathrm{C} 2}$ had no significant change in both peak relaxation time and area. 


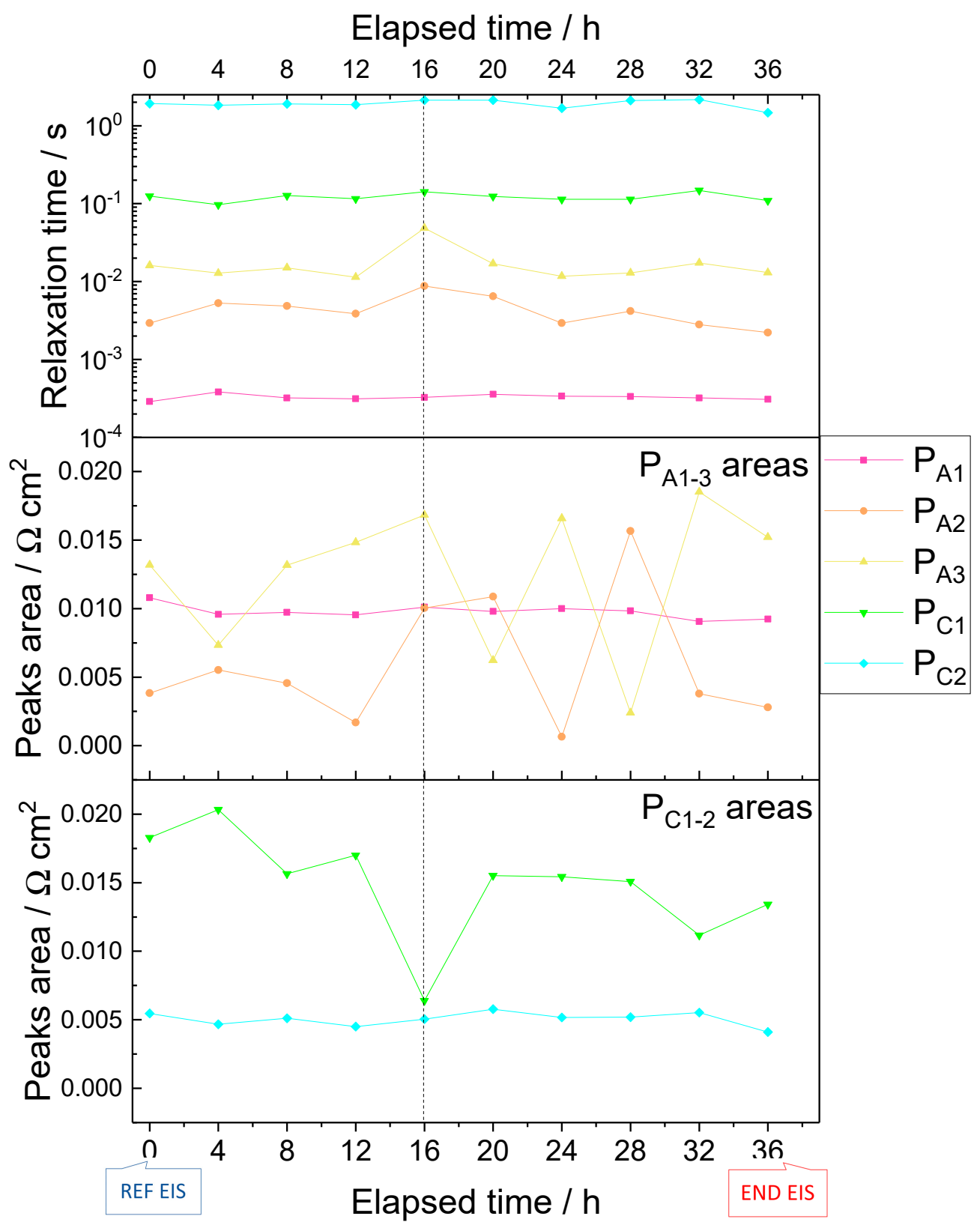

Figure 10. Relaxation time and area as a function of the experiment time. $\mathrm{T}=1048 \mathrm{~K}, \mathrm{H}_{2}: \mathrm{N}_{2}$ 27:75 $200 \mathrm{Sml} / \mathrm{min}$ at the $\mathrm{FE}$, air $300 \mathrm{Sml} / \mathrm{min}$ at the $\mathrm{AE}, \mathrm{j}=250 \mathrm{~mA} / \mathrm{cm}^{2}$.

\subsection{Diagnosis Validation}

The diagnosis validation was achieved thanks to post-mortem analysis of the exhausted specimen. The exhausted SOC specimen was taken out from the testing apparatus for further characterizations, namely SEM analysis and Micro-Raman spectroscopy. In Figure 12, the SEMs of both fuel electrode face and section of the cell are shown. Looking at the cells section micrographs $\left(A_{1}\right.$ and $\left.B_{1}\right)$, neither delamination's were observed at the electrode-electrolyte interface nor cracks on the electrode. Concerning the micrographs of FE faces, no coarsening of both Ni catalyst and YSZ particles nor agglomeration were detected. This means that the high-current stress test did not irreversibly damage the cell. To have a clearer view of the microstructural composition of the FE, Micro-Raman spectroscopy was employed (Figure 13). The pristine cell presented all the characteristics peaks of YSZ and NiO. The peaks at $157 \mathrm{~cm}^{-1}, 271 \mathrm{~cm}^{-1}, 333 \mathrm{~cm}^{-1}, 474 \mathrm{~cm}^{-1}$, and $650 \mathrm{~cm}^{-1}$ (labeled as $\Delta$ ) can be assigned to tetragonal $\mathrm{ZrO}_{2}$ [48]. Four peaks assignable to $\mathrm{NiO}$ can 
be observed at a wavenumber higher than $700 \mathrm{~cm}^{-1}$. Specifically, the two-phonon 2nd order transverse optical mode at $\approx 730 \mathrm{~cm}^{-1}\left(\mathrm{Ni}_{2 \mathrm{P}}\right)$, the two-phonon mode transverse optical + longitudinal mode at $\approx 906 \mathrm{~cm}^{-1}\left(\mathrm{Ni}_{2 \mathrm{P}}\right)$, the two-phonon 2nd order longitudinal optical mode at $\approx 1090 \mathrm{~cm}^{-1}\left(\mathrm{Ni}_{2 \mathrm{P}}\right)$, and at last the two-magnon mode at $\approx 1500 \mathrm{~cm}^{-1}$ (2M) $[49,50]$. No peaks of the one-phonon mode $\left(<700 \mathrm{~cm}^{-1}\right)$ appear, probably because they overlapped with the scattering of YSZ. As the cell is started, the NiO in the FE is reduced with $100 \% \mathrm{H}_{2}$ at $150 \mathrm{Sml} / \mathrm{min}$. Indeed, all the peaks coming from $\mathrm{NiO}$ scattering are no more visible, suggesting a complete reduction of $\mathrm{NiO}$ to metal $\mathrm{Ni}$.

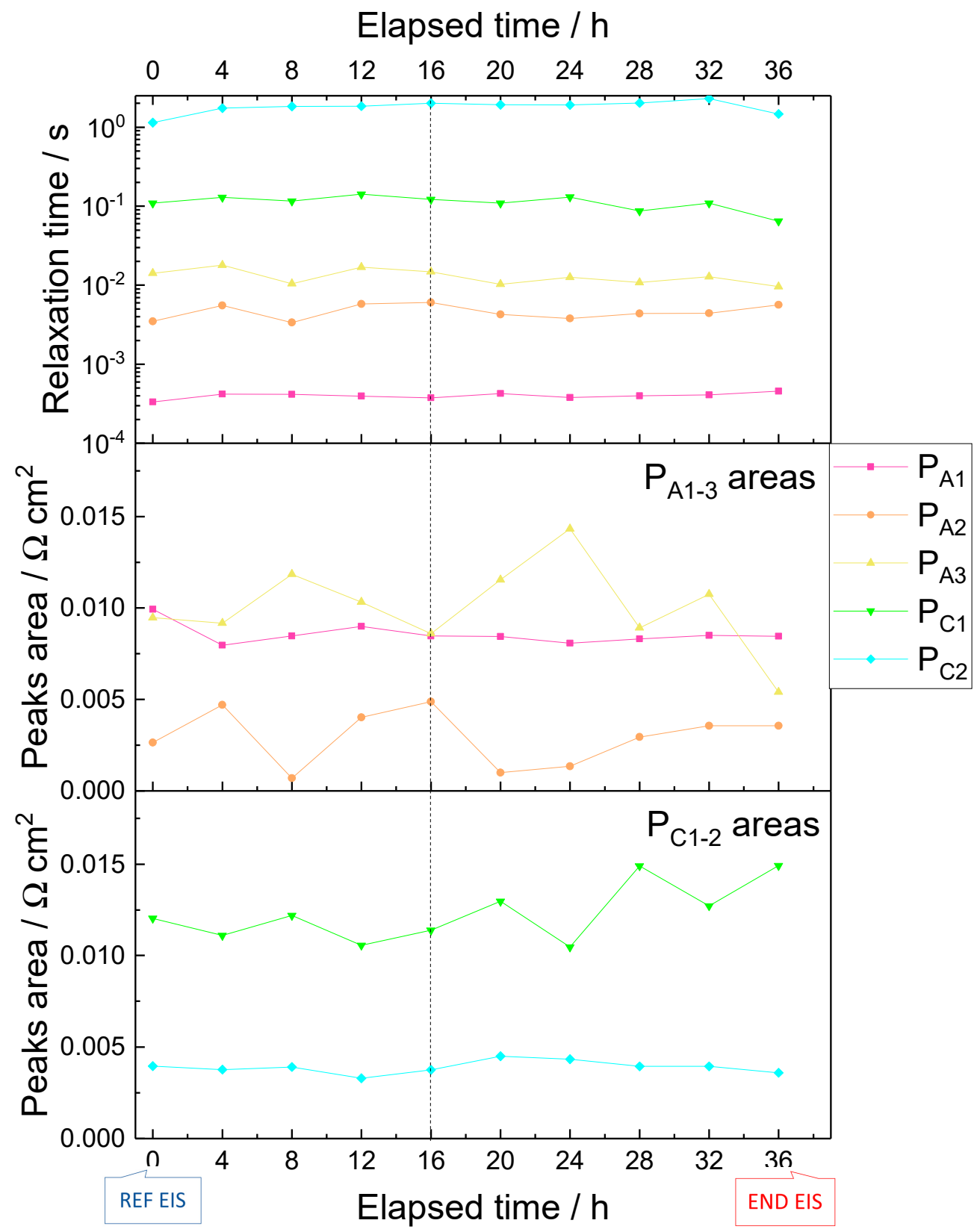

Figure 11. Relaxation time and area as a function of the experiment time. $\mathrm{T}=1048 \mathrm{~K}, \mathrm{H}_{2}: \mathrm{N}_{2} 27: 75$ $200 \mathrm{Sml} / \mathrm{min}$ at the $\mathrm{FE}$, air $300 \mathrm{Sml} / \mathrm{min}$ at the $\mathrm{AE}, \mathrm{j}=500 \mathrm{~mA} / \mathrm{cm}^{2}$. 

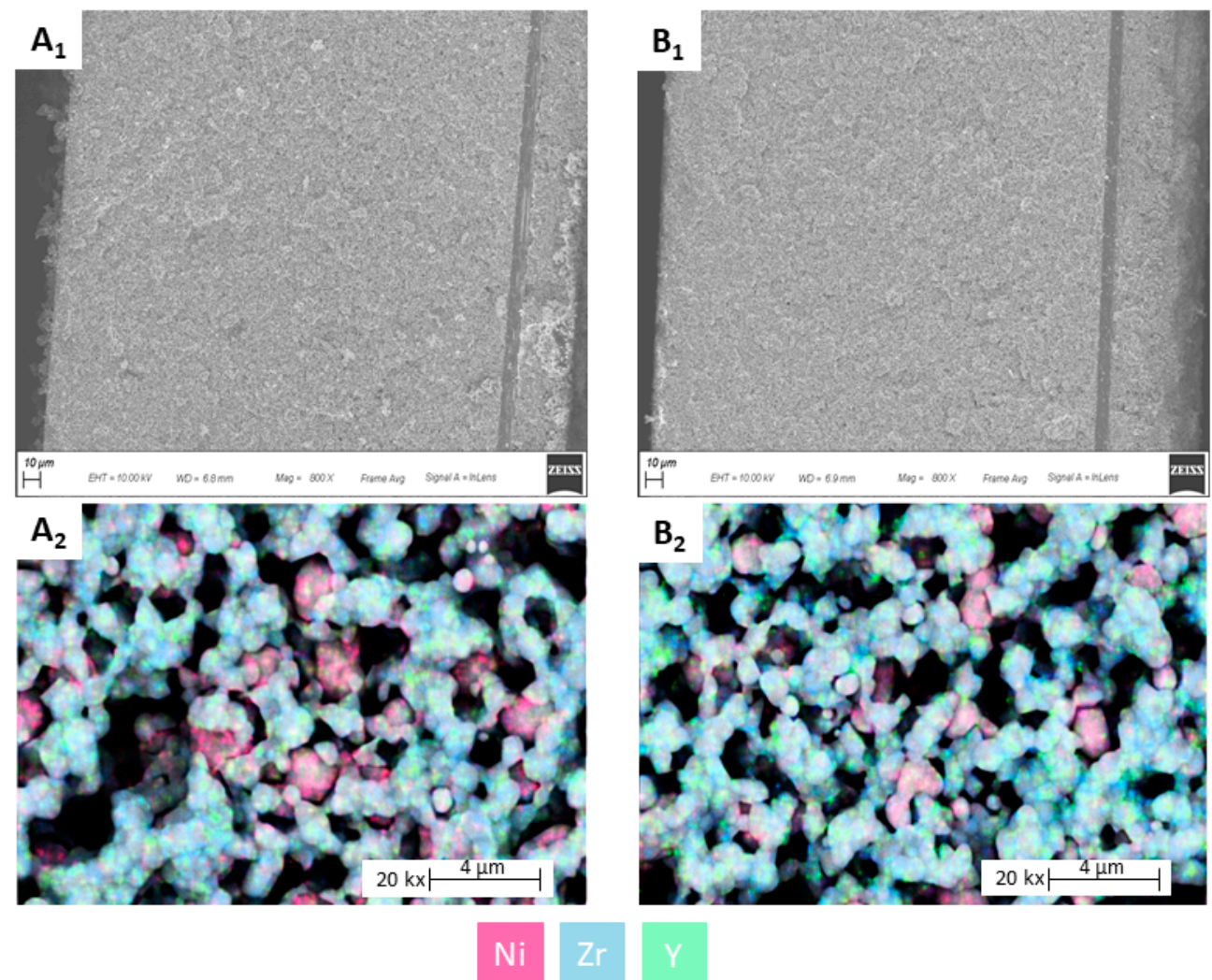

Figure 12. SEM micrographs of both section $(800 \times$ magnification $)$ and anode face $(20 \mathrm{kx}$ magnification) of the pristine cell after reduction $\left(\mathbf{A}_{1}, \mathbf{A}_{2}\right)$ and stressed SOC specimen $\left(\mathbf{B}_{1}, \mathbf{B}_{2}\right)$.

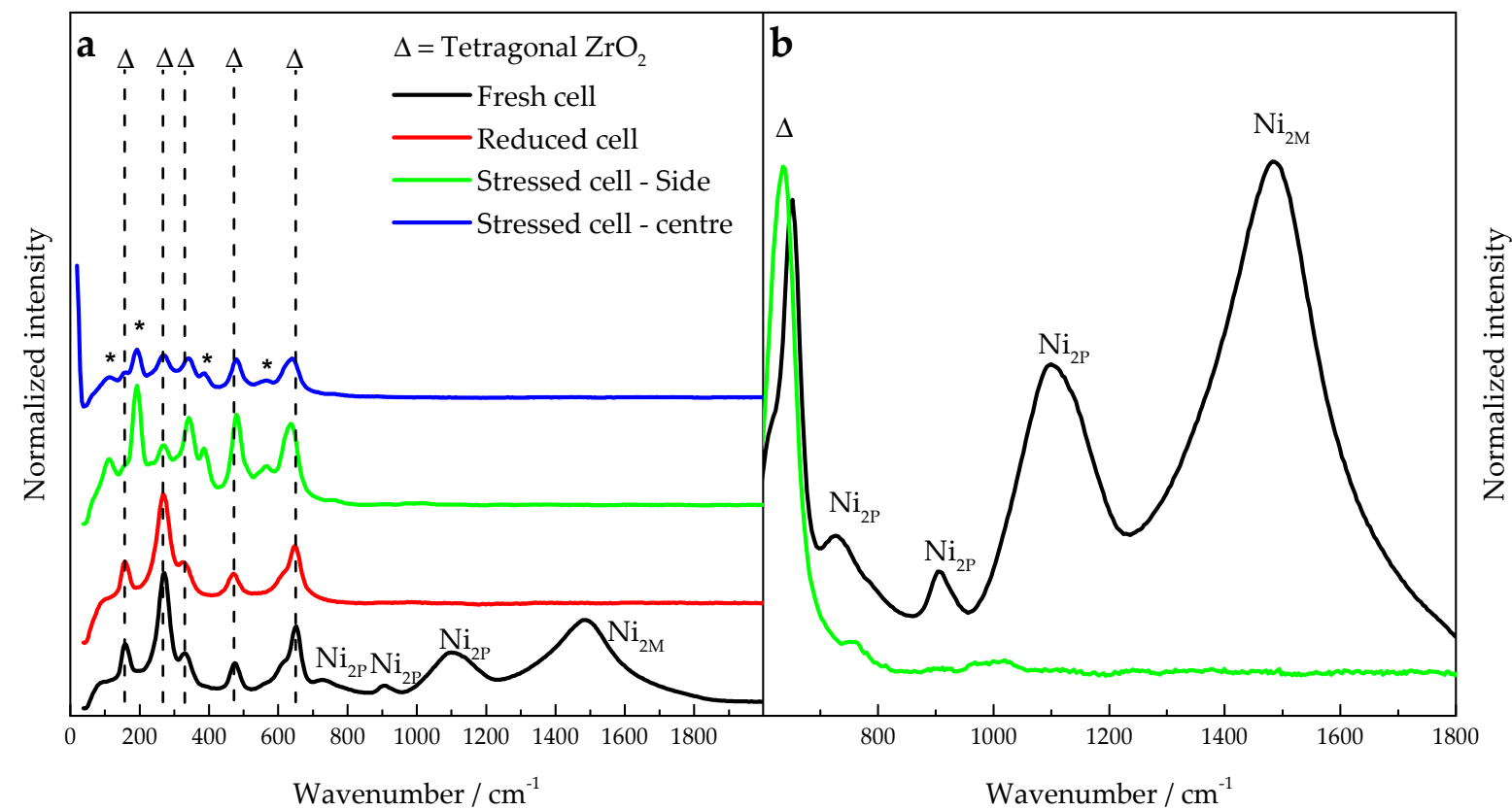

Figure 13. (a) Raman spectra of the pristine cell (black line), pristine reduced cell (red line), side of exhausted SOC specimen (green line), the center of exhausted SOC specimen (blue line). (b) Comparison of pristine cell and exhausted SOC specimen from 600 up to $1800 \mathrm{~cm}^{-1}$.

To study the composition on the exhausted SOC specimen, Raman spectra were acquired on two different spots, i.e., the center and near the circumference of the electrode. 
The peaks due to the scattering of tetragonal $\mathrm{ZrO}_{2}$ were still visible. Two peaks, which were at $474 \mathrm{~cm}^{-1}$ and $650 \mathrm{~cm}^{-1}$, shifted at $478 \mathrm{~cm}^{-1}$ and $640 \mathrm{~cm}^{-1}$, respectively. A new set of peaks appeared from $190 \mathrm{~cm}^{-1}$ up to $730 \mathrm{~cm}^{-1}$. These peaks were assigned to $\mathrm{NiO}$ as zone-boundary phonon mode $\left(190 \mathrm{~cm}^{-1}\right)$, one-phonon transverse optical mode $\left(380 \mathrm{~cm}^{-1}\right)$, one-phonon longitudinal optical mode $\left(570 \mathrm{~cm}^{-1}\right)$, and two-phonon 2nd order transverse optical mode $\left(730 \mathrm{~cm}^{-1}\right)$. The higher intensity of the one-phonon mode peaks can be explained by the defect-rich surface of the catalyst particles, probably induced by the stress test [49]. The two-phonon modes of $\mathrm{NiO}\left(>730 \mathrm{~cm}^{-1}\right)$ could be weak because of two factors: (i) the surface layer is amorphous, and (ii) the presence of adsorbate species on the surface such as oxygen or water [50]. Finally, the absence of the two-magnon peak $\left(1500 \mathrm{~cm}^{-1}\right)$ could be due to the laser-induced heating above the Néel temperature and the destruction of magnetic ordering [51].

\section{Discussion and Concluding Remarks}

In the test here proposed, the stress agent causing early degradation of the SOC material was known a priori. Thus, the comprehensive analysis of the evolution of DRT peaks features (center and area) revealed the effect of the stress test. Similar experiences might be conducted, perturbating the SOC operation with different stress agents. Nonetheless, the experimental evidence, profusely presented and discussed in Section 3, already provides a validation of the diagnostic technique here proposed, encompassing EIS signal analysis and post-mortem SOC material investigation. Therefore, the technique based on EIS and DRT can be implemented as a tool for SOC operando diagnosis. Real-time deconvolution of EIS data and the comparison of results with newEclean deconvoluted spectra allow identifying faults outbreak and deliver specific information on the leading cause behind performance loss. The detection of faults at the early stage is fundamental for process control and management and permits mitigation actions to reduce the stress on the SOC material; hence, preventing its performance from decaying beyond physiological rates.

The diagnostic tool here presented is related to a particular family of hydrogen electrochemical energy technologies, namely Solid Oxide Cells. As presented in the Introduction, this technology embeds a great potential in both fuel cell and electrolysis processes, as well as in reversible operated cells. Moreover, the methodology adopted in the diagnostic tool shows relevance in the broader framework of hydrogen energy conversion technologies. Hence, provided that DRT peaks are correctly identified, their utilization can be extended beyond solid oxide cells.

Author Contributions: Conceptualization, L.B.; methodology, A.B.; software, A.S.; validation, A.B., and A.S.; formal analysis, A.S. and F.N.; investigation, A.B.; resources, L.B.; data curation, A.S.; writing-original draft preparation, A.B. and A.S.; writing-review and editing, L.B. and F.N.; visualization, A.B. and A.S.; supervision, G.B.; project administration, L.B.; funding acquisition, L.B. All authors have read and agreed to the published version of the manuscript.

Funding: This research was funded by the Italian Ministry for Education and Research (MIUR), under the program "Progetti di Ricerca di rilevante Interesse Nazionale" (PRIN-2017)" in the context of HERMES (High Efficiency Reversible technologies in fully renewable Multi-Energy System project)_Prot. 2017F4S2L3.

Institutional Review Board Statement: Not applicable.

Informed Consent Statement: Not applicable.

Data Availability Statement: Data sharing not applicable.

Conflicts of Interest: The authors declare no conflict of interest. The funders had no role in the design of the study; in the collection, analyses, or interpretation of data; in the writing of the manuscript, or in the decision to publish the results. 


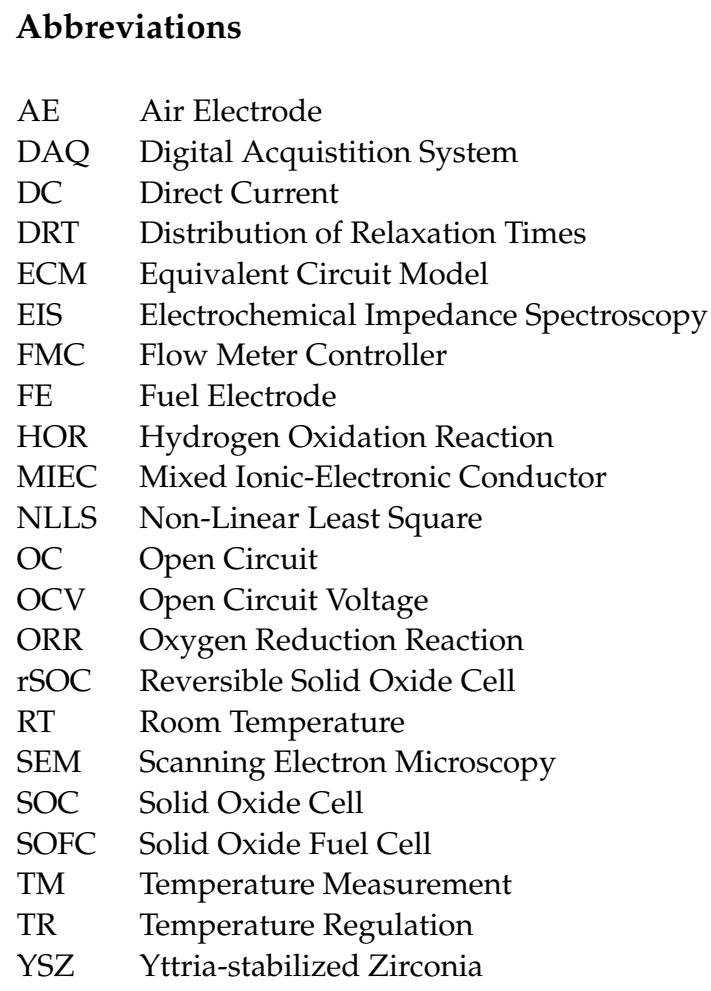

\section{References}

1. Venkataraman, V.; Pérez-Fortes, M.; Wang, L.; Hajimolana, Y.S.; Boigues-Muñoz, C.; Agostini, A.; McPhail, S.J.; Maréchal, F.; Van Herle, J.; Aravind, P. Reversible solid oxide systems for energy and chemical applications-Review \& perspectives. J. Energy Storage 2019, 24, 100782. [CrossRef]

2. Posdziech, O.; Schwarze, K.; Brabandt, J. Efficient hydrogen production for industry and electricity storage via high-temperature electrolysis. Int. J. Hydrogen Energy 2019, 44, 19089-19101. [CrossRef]

3. Bicer, Y.; Khalid, F. Life cycle environmental impact comparison of solid oxide fuel cells fueled by natural gas, hydrogen, ammonia and methanol for combined heat and power generation. Int. J. Hydrogen Energy 2020, 45, 3670-3685. [CrossRef]

4. Choudhury, A.; Chandra, H.; Arora, A. Application of solid oxide fuel cell technology for power generation-A review. Renew. Sustain. Energy Rev. 2013, 20, 430-442. [CrossRef]

5. Keçebaş, A.; Kayfeci, M.; Bayat, M. Electrochemical hydrogen generation. In Solar Hydrogen Production; Elsevier: Amsterdam, The Netherlands, 2019; pp. 299-317.

6. David, M.; Ocampo-Martínez, C.; Sánchez-Peña, R. Advances in alkaline water electrolyzers: A review. J. Energy Storage 2019, 23, 392-403. [CrossRef]

7. Bianchi, F.R.; Baldinelli, A.; Barelli, L.; Cinti, G.; Audasso, E.; Bosio, B. Multiscale Modeling for Reversible Solid Oxide Cell Operation. Energies 2020, 13, 5058. [CrossRef]

8. Frank, M.; Deja, R.; Peters, R.; Blum, L.; Stolten, D. Bypassing renewable variability with a reversible solid oxide cell plant. Appl. Energy 2018, 217, 101-112. [CrossRef]

9. Nguyen, V.N.; Fang, Q.; Packbier, U.; Blum, L. Long-term tests of a Jülich planar short stack with reversible solid oxide cells in both fuel cell and electrolysis modes. Int. J. Hydrogen Energy 2013, 38, 4281-4290. [CrossRef]

10. Hanasaki, M.; Uryu, C.; Daio, T.; Kawabata, T.; Tachikawa, Y.; Lyth, S.M.; Shiratori, Y.; Taniguchi, S.I.; Sasaki, K. SOFC Durability against Standby and Shutdown Cycling. J. Electrochem. Soc. 2014, 161, F850-F860. [CrossRef]

11. Cooper, S.J.; Brandon, N.P. An Introduction to Solid Oxide Fuel Cell Materials, Technology and Applications; Elsevier Ltd.: Amsterdam, The Netherlands, 2017.

12. Petipas, F.; Fu, Q.; Brisse, A.; Bouallou, C. Transient operation of a solid oxide electrolysis cell. Int. J. Hydrogen Energy 2013, 38, 2957-2964. [CrossRef]

13. Preininger, M.; Stoeckl, B.; Subotić, V.; Hochenauer, C.; Stöckl, B. Extensive analysis of an SOC stack for mobile application in reversible mode under various operating conditions. Electrochimica Acta 2019, 299, 692-707. [CrossRef]

14. Baldinelli, A.; Barelli, L.; Bidini, G.; Discepoli, G. Economics of innovative high capacity-to-power energy storage technologies pointing at 100\% renewable micro-grids. J. Energy Storage 2020, 28, 101198. [CrossRef]

15. Pfeifer, T.; Reuber, S.; Hartmann, M.; Barthel, M.; Baade, J.; Matyáš, J.; Balaya, P.; Singh, D.; Wei, J. SOFC System Development and Held Trials for Commercial Applications. Process. High Temp. Supercond. 2016, 255, 61-75. [CrossRef] 
16. Khan, M.S.; Lee, S.-B.; Song, R.-H.; Lee, J.-W.; Lim, T.-H.; Park, S.-J. Fundamental mechanisms involved in the degradation of nickel-yttria stabilized zirconia (Ni-YSZ) anode during solid oxide fuel cells operation: A review. Ceram. Int. 2016, 42, 35-48. [CrossRef]

17. Sasaki, K.; Susuki, K.; Iyoshi, A.; Uchimura, M.; Imamura, N.; Kusaba, H.; Teraoka, Y.; Fuchino, H.; Tsujimoto, K.; Uchida, Y.; et al. $\mathrm{H}_{2} \mathrm{~S}$ Poisoning of Solid Oxide Fuel Cells. J. Electrochem. Soc. 2006, 153, A2023-A2029. [CrossRef]

18. Sreedhar, I.; Agarwal, B.; Goyal, P.; Agarwal, A. An overview of degradation in solid oxide fuel cells-potential clean power sources. J. Solid State Electrochem. 2020, 24, 1239-1270. [CrossRef]

19. Jiang, S.P.; Zhen, Y. Mechanism of $\mathrm{Cr}$ deposition and its application in the development of Cr-tolerant cathodes of solid oxide fuel cells. Solid State Ionics 2008, 179, 1459-1464. [CrossRef]

20. Fergus, J. Effect of cathode and electrolyte transport properties on chromium poisoning in solid oxide fuel cells. Int. J. Hydrogen Energy 2007, 32, 3664-3671. [CrossRef]

21. Trembly, J.; Gemmen, R.; Bayless, D. The effect of coal syngas containing $\mathrm{HCl}$ on the performance of solid oxide fuel cells: Investigations into the effect of operational temperature and $\mathrm{HCl}$ concentration. J. Power Sources 2007, 169, 347-354. [CrossRef]

22. El Gabaly, F.; Mccarty, K.F.; Bluhm, H.; McDaniel, A.H. Oxidation stages of Ni electrodes in solid oxide fuel cell environments. Phys. Chem. Chem. Phys. 2013, 15, 8334-8341. [CrossRef]

23. Li, X.; Blinn, K.; Chen, D.; Liu, M. In Situ and Surface-Enhanced Raman Spectroscopy Study of Electrode Materials in Solid Oxide Fuel Cells. Electrochem. Energy Rev. 2018, 1, 433-459. [CrossRef]

24. Li, X.; Lee, J.-P.; Blinn, K.S.; Chen, D.; Yoo, S.; Kang, B.; Bottomley, L.A.; El-Sayed, M.A.; Park, S.; Liu, M. High-temperature surface enhanced Raman spectroscopy for in situ study of solid oxide fuel cell materials. Energy Environ. Sci. 2013, 7, 306-310. [CrossRef]

25. Swallow, J.G.; Lee, J.K.; Defferriere, T.; Hughes, G.M.; Raja, S.N.; Tuller, H.L.; Warner, J.H.; Van Vliet, K.J. Atomic Resolution Imaging of Nanoscale Chemical Expansion in $\operatorname{Pr}_{x} \mathrm{Ce}_{1-x} \mathrm{O}_{2-\delta}$ during In Situ Heating. ACS Nano 2018, 12, 1359-1372. [CrossRef]

26. Hwang, S.; Chen, X.; Zhou, G.; Su, D. In Situ Transmission Electron Microscopy on Energy-Related Catalysis. Adv. Energy Mater. 2020, 10, 1902105. [CrossRef]

27. Stangl, A.; Munoz-Rojas, D.; Burriel, M. In situ and operando characterisation techniques for solid oxide electrochemical cells: Recent advances. J. Phys. Energy 2020, 3, 12001. [CrossRef]

28. Baldinelli, A.; Barelli, L.; Bidini, G.; Di Cicco, A.; Gunnella, R.; Minicucci, M.; Trapananti, A. Advancements regarding in-operando diagnosis techniques for solid oxide cells NiYSZ cermets. AIP Conf. Proc. 2019, 2191, 020012. [CrossRef]

29. Nielsen, J.; Hjelm, J. Impedance of SOFC electrodes: A review and a comprehensive case study on the impedance of LSM:YSZ cathodes. Electrochimica Acta 2014, 115, 31-45. [CrossRef]

30. Nobili, F.; Tossici, R.; Marassi, R.; Croce, F.; Scrosati, B. An AC Impedance Spectroscopic Study of $\mathrm{Li}_{x} \mathrm{CoO}_{2}$ at Different Temperatures. J. Phys. Chem. B 2002, 106, 3909-3915. [CrossRef]

31. Pitarch-Tena, D.; Ngo, T.T.; Vallés-Pelarda, M.; Pauporté, T.; Mora-Seró, I. Impedance Spectroscopy Measurements in Perovskite Solar Cells: Device Stability and Noise Reduction. ACS Energy Lett. 2018, 3, 1044-1048. [CrossRef]

32. Schwartz, M. The theory of impedance in biological systems. J. Biol. Phys. 1973, 1, 123-142. [CrossRef]

33. Kornely, M.; Neumann, A.; Menzler, N.H.; Leonide, A.; Weber, A.; Ivers-Tiffée, E. Degradation of anode supported cell (ASC) performance by Cr-poisoning. J. Power Sources 2011, 196, 7203-7208. [CrossRef]

34. Kromp, A.; Dierickx, S.; Leonide, A.; Weber, A.; Iverstiffee, E. Electrochemical Analysis of Sulfur-Poisoning in Anode Supported SOFCs Fuelled with a Model Reformate. J. Electrochem. Soc. 2012, 159, B597-B601. [CrossRef]

35. Sumi, H.; Shimada, H.; Yamaguchi, Y.; Yamaguchi, T.; Fujishiro, Y. Degradation evaluation by distribution of relaxation times analysis for microtubular solid oxide fuel cells. Electrochimica Acta 2020, 339, 135913. [CrossRef]

36. Dierickx, S.; Weber, A.; Ivers-Tiffée, E. How the distribution of relaxation times enhances complex equivalent circuit models for fuel cells. Electrochimica Acta 2020, 355, 136764. [CrossRef]

37. Boukamp, B.A. A Nonlinear Least Squares Fit procedure for analysis of immittance data of electrochemical systems. Solid State Ionics 1986, 20, 31-44. [CrossRef]

38. Macdonald, J.R. Impedance spectroscopy: Old problems and new developments. Electrochimica Acta 1990, 35, 1483-1492. [CrossRef]

39. Bartoszek, J.; Liu, Y.-X.; Karczewski, J.; Wang, S.-F.; Mrozinski, A.; Jasiński, P. Distribution of relaxation times as a method of separation and identification of complex processes measured by impedance spectroscopy. In Proceedings of the $201721 \mathrm{st}$ European Microelectronics and Packaging Conference (EMPC) \& Exhibition, Warsaw, Poland, 10-13 September 2017; pp. 1-5.

40. Baldinelli, A.; Staffolani, A.; Bidini, G.; Barelli, L.; Nobili, F. An extensive model for renewable energy electrochemical storage with Solid Oxide Cells based on a comprehensive analysis of impedance deconvolution. J. Energy Storage 2021, 33, 102052. [CrossRef]

41. Boukamp, B. Practical application of the Kramers-Kronig transformation on impedance measurements in solid state electrochemistry. Solid State Ionics 1993, 62, 131-141. [CrossRef]

42. Wan, T.H.; Saccoccio, M.; Chen, C.; Ciucci, F. Influence of the Discretization Methods on the Distribution of Relaxation Times Deconvolution: Implementing Radial Basis Functions with DRTtools. Electrochimica Acta 2015, 184, 483-499. [CrossRef]

43. Papurello, D.; Menichini, D.; Lanzini, A. Distributed relaxation times technique for the determination of fuel cell losses with an equivalent circuit model to identify physicochemical processes. Electrochimica Acta 2017, 258, 98-109. [CrossRef] 
44. Muñoz, C.B.; Pumiglia, D.; McPhail, S.J.; Montinaro, D.; Comodi, G.; Santori, G.; Carlini, M.; Polonara, F. More accurate macromodels of solid oxide fuel cells through electrochemical and microstructural parameter estimation-Part I: Experimentation. J. Power Sources 2015, 294, 658-668. [CrossRef]

45. Leonide, A.; Sonn, V.; Weber, A.; Ivers-Tiffée, E. Evaluation and Modeling of the Cell Resistance in Anode-Supported Solid Oxide Fuel Cells. J. Electrochem. Soc. 2008, 155, B36-B41. [CrossRef]

46. Macdonald, J.R. Impedance Spectroscopy: Emphasizing Solid Materials and Systems; Wiley-Interscience: Hoboken, NJ, USA, 1987.

47. Adler, S.B.; Lane, J.A.; Steele, B.C.H. Electrode Kinetics of Porous Mixed-Conducting Oxygen Electrodes. J. Electrochem. Soc. 1996, 143, 3554-3564. [CrossRef]

48. Basahel, S.N.; Ali, T.T.; Mokhtar, M.; Narasimharao, K. Influence of crystal structure of nanosized $\mathrm{ZrO}_{2}$ on photocatalytic degradation of methyl orange. Nanoscale Res. Lett. 2015, 10, 73. [CrossRef]

49. Mironova-Ulmane, N.; Kuzmin, A.; Steins, I.; Grabis, J.; Sildos, I.; Pärs, M. Raman scattering in nanosized nickel oxide NiO. J. Phys. Conf. Ser. 2007, 93, 012039. [CrossRef]

50. Burmistrov, I.; Agarkov, D.; Tartakovskii, I.; Kharton, V.; Bredikhin, S. Performance Optimization of Cermet SOFC Anodes: An Evaluation of Nanostructured NiO. ECS Meet. Abstr. 2015, 68, 1265-1274. [CrossRef]

51. Mironova-Ulmane, N.; Kuzmin, A.; Sildos, I.; Puust, L.; Grabis, J. Magnon and Phonon Excitations in Nanosized NiO. Latv. J. Phys. Tech. Sci. 2019, 56, 61-72. [CrossRef] 